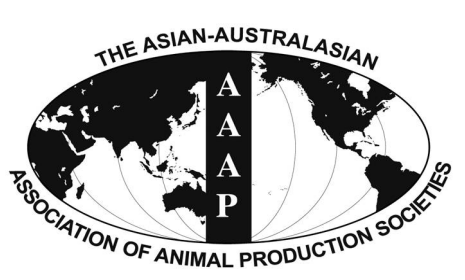

Open Access

Asian Australas. J. Anim. Sci.

Vol. 29, No. 6 : $807-813$ June 2016

http://dx.doi.org/10.5713/ajas.15.0641

www.ajas.info

pISSN 1011-2367 elSSN 1976-5517

\title{
Effects of Rumen Protozoa of Brahman Heifers and Nitrate on Fermentation and In vitro Methane Production
}

\author{
S. H. Nguyen ${ }^{1,2, *}$, L. Li ${ }^{1}$, and R. S. Hegarty ${ }^{1}$ \\ ${ }^{1}$ School of Environmental and Rural Sciences, University of New England, Armidale, NSW 2351, Australia
}

\begin{abstract}
Two experiments were conducted assessing the effects of presence or absence of rumen protozoa and dietary nitrate addition on rumen fermentation characteristics and in vitro methane production in Brahman heifers. The first experiment assessed changes in rumen fermentation pattern and in vitro methane production post-refaunation and the second experiment investigated whether addition of nitrate to the incubation would give rise to methane mitigation additional to that contributed by defaunation. Ten Brahman heifers were progressively adapted to a diet containing $4.5 \%$ coconut oil distillate for $18 \mathrm{~d}$ and then all heifers were defaunated using sodium 1-(2-sulfonatooxyethoxy) dodecane (Empicol). After $15 \mathrm{~d}$, the heifers were given a second dose of Empicol. Fifteen days after the second dosing, all heifers were allocated to defaunated or refaunated groups by stratified randomisation, and the experiment commenced $(\mathrm{d} 0)$. On $\mathrm{d} 0$, an oral dose of rumen fluid collected from unrelated faunated cattle was used to inoculate 5 heifers and form a refaunated group so that the effects of re-establishment of protozoa on fermentation characteristics could be investigated. Samples of rumen fluid collected from each animal using oesophageal intubation before feeding on $\mathrm{d} 0,7,14$, and 21 were incubated for in vitro methane production. On d 35, $2 \%$ nitrate (as $\mathrm{NaNO}_{3}$ ) was included in in vitro incubations to test for additivity of nitrate and absence of protozoa effects on fermentation and methane production. It was concluded that increasing protozoal numbers were associated with increased methane production in refaunated heifers 7, 14, and $21 \mathrm{~d}$ after refaunation. Methane production rate was significantly higher from refaunated heifers than from defaunated heifers $35 \mathrm{~d}$ after refaunation. Concentration and proportions of major volatile fatty acids, however, were not affected by protozoal treatments. There is scope for further reducing methane output through combining defaunation and dietary nitrate as the addition of nitrate in the defaunated heifers resulted in $86 \%$ reduction in methane production in vitro. (Key Words: Defaunation, Refaunation, Nitrate, Fermentation and Methane Production)
\end{abstract}

\section{INTRODUCTION}

Reviews of the effects of enteric protozoa on digestion and productivity by ruminants have concluded removal of rumen ciliate protozoa reduces enteric methane $\left(\mathrm{CH}_{4}\right)$ emission by 13\% (Newbold et al., 2015) and increases an average daily gain by $11 \%$ (Eugène et al., 2004). Finlay et al. (1994) concluded that methanogens existing as endoand ecto-symbionts with ciliate protozoa contributed 37\% of rumen $\mathrm{CH}_{4}$ production and Stumm et al. (1982) identified that $10 \%$ to $20 \%$ of rumen methanogens were attached on

\footnotetext{
* Corresponding Author: S. H. Nguyen. Tel: +61-449169668, Fax:+61-267732362, E-mail: nghson.niah@gmail.com

${ }^{2}$ National Institute of Animal Sciences, Thuy Phuong, Tu Liem, Hanoi, Vietnam.

Submitted Jul. 30, 2015; Revised Nov. 18, 2015; Accepted Dec. 22, 2015
}

the outside of protozoa. Centrifuging rumen fluid to remove protozoa reduced the methanogen population by $78 \%$ (Newbold et al., 1995).

Methane production is positively related to the size of the rumen protozoal population (Morgavi et al., 2010) and the absence of protozoa reduces $\mathrm{CH}_{4}$ production and significantly modifies fermentation characteristics in vitro (Qin et al., 2012). However, Ranilla et al. (2007) reported that there was no correlation between methanogenesis and protozoal biomass per unit of feed degraded in vitro. Further, Bird et al. (2008) showed that defaunation did not change enteric $\mathrm{CH}_{4}$ production 10 to 25 weeks post-treatment. Hegarty et al. (2008) also reported that rumen protozoa did not affect $\mathrm{CH}_{4}$ production by lambs raised without protozoa from birth, or defaunated at weaning. Therefore, the role of protozoa in methanogenesis is unclear. 
In contrast, dietary nitrate $\left(\mathrm{NO}_{3}\right)$ reduces $\mathrm{CH}_{4}$ reliably and predictably (van Zijderveld et al., 2010; 2011). Nitrate reduces total gas production when rumen fluid is incubated in vitro, and it changes the volatile fatty acids (VFA) profile by increasing acetate and reducing propionate and butyrate molar proportions while total VFA concentration is unaffected (Lin et al., 2011).

The objectives of these studies were to describe the fermentation characteristics and $\mathrm{CH}_{4}$ emission changes occurring in the period after refaunation of previously protozoa-free heifers, and assess whether $\mathrm{NO}_{3}$ could further reduce $\mathrm{CH}_{4}$ production from defaunated animals.

\section{MATERIALS AND METHODS}

\section{Animals and feeding}

All protocols for treatment and care of the cattle were approved by the University of New England Animal Ethics Committee (AEC 13-054). Ten Brahman heifers (8 months of age) with an average liveweight of $274 \pm 32.8 \mathrm{~kg}$ were used. Cattle were adapted to a pre-experimental diet of oaten $(70 \%)$ and lucerne (30\%) chaff with initial inclusion of $1 \%$ of coconut oil distillate (COD) which was raised to a final level of $4.5 \%$ over $8 \mathrm{~d}$. Cattle were then changed to an experimental diet of for $10 \mathrm{~d}$ to eliminate rumen protozoa comprising oaten chaff $(70 \%)$, lucerne chaff $(21 \%)$, COD $(4.5 \%)$ and molasses $(4.5 \%)$, resulting in $88.1 \%$ dry matter (DM) in the mixed ration and $7.9 \%$ crude protein and $5 \%$ crude fat in the DM. This combined $18 \mathrm{~d}$ period of COD dietary treatment reduced the protozoal population from $3.91 \times 10^{5}$ cells $/ \mathrm{mL}$ to $0.58 \times 10^{5}$ cells $/ \mathrm{mL}$ of rumen fluid and all cattle were then treated with a chemical to defaunate. After the defaunation treatment, all cattle were given a diet of oaten $(70 \%)$ and lucerne chaff $(30 \%)$ which included $10.5 \%$ crude protein; 1.3 crude fat; $88.8 \%$ DM for the remainder of the study. All cattle had ad libitum access to the ration and water.

\section{Defaunation of cattle}

After $18 \mathrm{~d}$ feeding COD, all feed was withdrawn for a day and cattle were orally dosed with sodium 1-(2sulfonatooxyethoxy) dodecane (Empicol ESB/70AV, Allright and Wilson Australia Ltd, Melbourne, Australia) administered at $45 \mathrm{~g} / \mathrm{d}$ in a $10 \% \mathrm{v} / \mathrm{v}$ solution to remove protozoa. Cattle were dosed on three consecutive days and feed was withheld during this treatment protocol, which was described by Bird and Light (2013). Animals required $15 \mathrm{~d}$ to fully recover their previous voluntary intake and received the COD diet during this period of time. The three day dosing with Empicol was then repeated commencing 15 $\mathrm{d}$ after the first dosing. A further $15 \mathrm{~d}$ after the second drenching program, rumen fluid samples were collected for protozoa enumeration and the experiment commenced (d 0).

\section{Refaunation of cattle}

On d 0 all cattle had recovered their intake and wellbeing, and rumen fluid of the animals was observed to be free of protozoa. Cattle were allocated to defaunated ( $n=$ $5)$ and refaunated groups $(n=5)$ by stratified randomisation based on liveweight. A single oral dose $(500 \mathrm{~mL} /$ heifer $)$ of a mixed rumen fluid collected from two cannulated faunated cattle grazing pasture was used to refaunate 5 heifers. The protozoal population in the inoculum $\left(3.42 \times 10^{5} \mathrm{cells} / \mathrm{mL}\right)$ consisted of large holotrich $\left(0.13 \times 10^{5}\right.$ cells $\left./ \mathrm{mL}\right)$, small holotrich $\left(0.5 \times 10^{5}\right.$ cells $\left./ \mathrm{mL}\right)$ and small entodiniomorphs $\left(2.79 \times 10^{5}\right.$ cells $\left./ \mathrm{mL}\right)$.

\section{Rumen fluid sampling, ammonia, volatile fatty acid concentrations, and protozoal enumeration}

In experiment 1 , samples of rumen fluid $(40 \mathrm{~mL})$ were collected using oesophageal intubation from defaunated and refaunated heifers before feeding on d $0,7,14$, and 21 . Samples from defaunated heifers were immediately checked under a microscope to confirm that defaunated heifers were protozoa-free. Rumen $\mathrm{pH}$ was measured immediately using a portable $\mathrm{pH}$ meter (Orion 230 Aplus, Thermo Scientific, Beverly, MA, USA). A $15 \mathrm{~mL}$ subsample was placed in wide-neck McCartney bottle acidified with $0.25 \mathrm{~mL}$ of 18 $\mathrm{M}$ sulphuric acid and stored at $-20^{\circ} \mathrm{C}$ for VFA and ammonia $\left(\mathrm{NH}_{3}\right)$ analyses. A $4 \mathrm{~mL}$ subsample was placed in wide-neck McCartney bottle containing $16 \mathrm{~mL}$ of formaldehyde-saline $(4 \%$ formalin $\mathrm{v} / \mathrm{v}$ ) for protozoa enumeration. Protozoa were counted using a Fuchs-Rosenthal optic counting chamber $\left(0.0625 \mathrm{~mm}^{2}\right.$ and $0.2 \mathrm{~mm}$ of depth) using a staining technique adapted from the procedure of Dehority (1984). The protozoa were differentiated into large $(>100 \mu \mathrm{m})$ and small $(<100 \mu \mathrm{m})$ holotrich and entodiniomorph groupings. Another $20 \mathrm{~mL}$ of subsample from defaunated and refaunated heifers was used to conduct in vitro incubations for methane measurements.

In experiment 2 , samples of rumen fluid $(\sim 20 \mathrm{~mL})$ were collected on d 35 using oesophageal intubation from defaunated and refaunated heifers before feeding, with each sample being processed individually and its incubation started immediately after collection. The VFA concentrations were determined by gas chromatography using a Varian CP 3800 Gas Chromatography (Varian Inc. Palo Alto, CA, USA) and $\mathrm{NH}_{3}$ concentration was analysed using a modified Berthelot reaction using a continuous flow analyser (San ${ }^{++}$, Skalar, Breda, The Netherlands).

\section{In vitro incubations and measurements}

In vitro incubations $(23 \mathrm{~h})$ were conducted using rumen fluid collected from defaunated and refaunated heifers on $\mathrm{d}$ $0,7,14$, and 21 after refaunation, to assess changes in $\mathrm{CH}_{4}$ 
production in defaunated and refaunated heifers, while rumen protozoa were re-establishing in refaunated heifers (experiment 1). Samples taken on d 35 were incubated in vitro with the addition of $2 \% \mathrm{NO}_{3}$ (as $\mathrm{NaNO}_{3}$ ) of substrate $\mathrm{DM}$ to test for additivity of $\mathrm{NO}_{3}$ and defaunation effects on fermentation and $\mathrm{CH}_{4}$ production (experiment 2). The $\mathrm{NaNO}_{3}$ was dissolved in purified water and added in buffer solution. The composition of incubation buffer was adapted and modified after Soliva and Hess (2007). For all in vitro incubations, $20 \mathrm{~mL}$ of rumen fluid from each animal was injected into a Schott bottle $(100 \mathrm{~mL})$ which contained 40 $\mathrm{mL}$ of buffer solution under a constant flow of anaerobic $\mathrm{CO}_{2}$ in a water bath maintained at $39^{\circ} \mathrm{C}$. Mixed rumen fluid and buffer solution $(10 \mathrm{~mL})$ was transferred into three 50 $\mathrm{mL}$ syringes (Luer lock: Terumo Corporation, Tokyo, Japan) which contained $200 \pm 20 \mathrm{mg}$ of ground substrate ( $70 \%$ oaten and $30 \%$ lucerne chaff). The syringes were sealed by a 3-way tap, pre-warmed to $39^{\circ} \mathrm{C}$ and then incubated in a shaking water bath at $39^{\circ} \mathrm{C}$. After the incubations, gas volume was measured, liquid was drained from the syringes and placed in wide-neck McCartney bottle acidified with $0.25 \mathrm{~mL}$ of $18 \mathrm{M}$ sulphuric acid and stored at $-20^{\circ} \mathrm{C}$ for VFA and $\mathrm{NH}_{3}$ analyses. The gas in the syringes were analysed for $\mathrm{CH}_{4}$ concentration using a Varian CP 4900 Gas Chromatography (Varian Inc., USA).

\section{Statistical analyses}

Data were statistically analysed using SAS 9.0 (SAS Inst., Cary, NC, USA). Data from experiment 1 were subject to repeated-measures analysis of variance in PROC MIXED with protozoa, time and protozoa $\times$ time interaction as fixed factors. Data from experiment 2 were subject to analysis of variance in PROC GLM, factors being protozoa, $\mathrm{NO}_{3}$ and protozoa $\times \mathrm{NO}_{3}$ interaction. Means were analysed using the least squares means (LSMEANS) procedure. A probability of $<5 \%$ was considered to be statistically

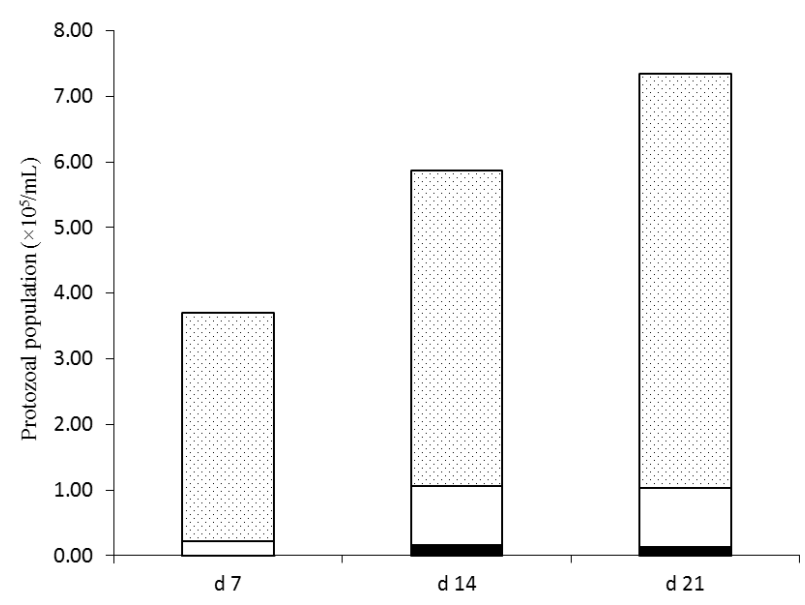

Figure 1. Small holotrich (口), large holotrich (ロ) and small entodiniomorphs (f) from refaunated heifers 7, 14 and $21 \mathrm{~d}$ after refaunation.

significant.

\section{RESULTS}

\section{Protozoal population in refaunated heifers}

Protozoa were not observed in any rumen fluid samples collected from defaunated heifers during this study. In refaunated heifers, however, the protozoal population reached $3.70 \times 10^{5}$ cells $/ \mathrm{mL}$ by $\mathrm{d} 7$ and almost doubled by d $21\left(7.01 \times 10^{5}\right.$ cells $\left./ \mathrm{mL}\right)$. Small entodiniomorphs were predominant in the total population, accounting for $94 \%$, $82 \%$, and $86 \%$ of the total counts at $d 7,14$, and 21 , respectively (Figure 1). Methane production from refaunated heifers was positively correlated with protozoal numbers although $\mathrm{CH}_{4}$ production tended to stabilise after $\mathrm{d}$ 14 (Figure 2).

\section{In vivo fermentation pattern and in vitro methane}

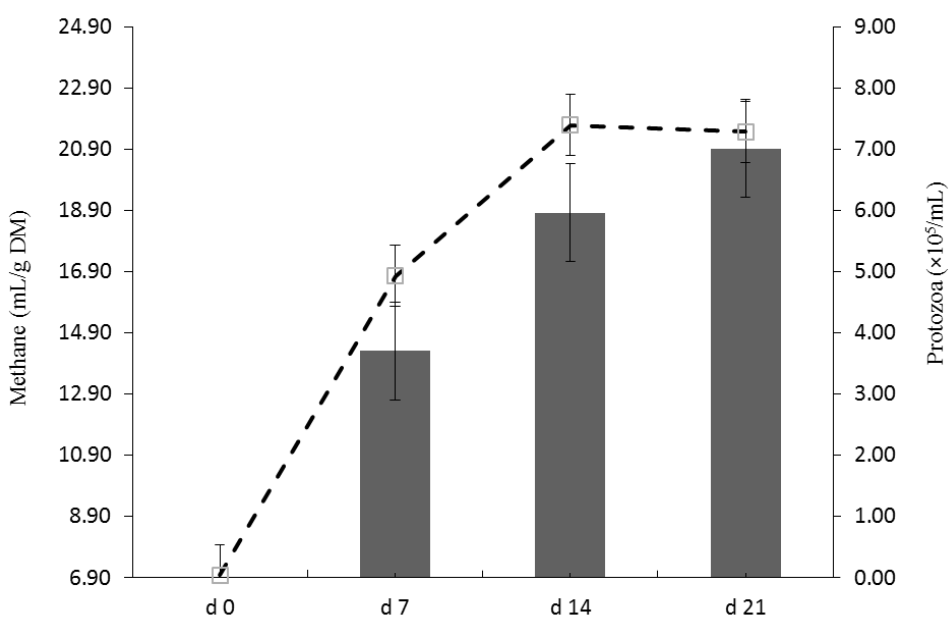

Figure 2. Methane production ( $\square$ ) and protozoal population ( $\square$ ) in rumen fluid from refaunated heifers $0,7,14$, and $21 \mathrm{~d}$ after refaunation using a mixed rumen fluid inoculum. Error bars indicate standard error of the mean. 
Table 1. The $\mathrm{pH}$, ammonia concentration and concentration and molar proportions of major volatile fatty acids (VFA) in rumen fluid, and changes in gas and methane production in-vitro after refaunation

\begin{tabular}{|c|c|c|c|c|c|c|c|c|c|c|c|c|}
\hline \multirow{3}{*}{ Item $^{1}$} & \multicolumn{8}{|c|}{ Treatment } & \multirow{3}{*}{ SEM } & \multicolumn{3}{|c|}{ p-values } \\
\hline & \multicolumn{4}{|c|}{ Defaunated } & \multicolumn{4}{|c|}{ Refaunated } & & \multirow{2}{*}{ Trt } & \multirow{2}{*}{ Time } & \multirow{2}{*}{ Trt $\times$ time } \\
\hline & Day 0 & Day 7 & Day 14 & Day 21 & Day 0 & Day 7 & Day 14 & Day 21 & & & & \\
\hline $\mathrm{pH}$ & 6.41 & 6.46 & 6.87 & 6.83 & 6.62 & 6.69 & 6.86 & 6.91 & 0.10 & 0.02 & $<0.001$ & 0.34 \\
\hline Ammonia (mg/L) & 32.68 & 30.76 & 59.04 & 62.92 & 36.88 & 69.52 & 86.24 & 117.00 & 9.56 & $<0.01$ & $<0.001$ & 0.08 \\
\hline Total VFA(mM/L) & 64.43 & 59.67 & 50.92 & 57.95 & 59.46 & 63.43 & 63.03 & 58.16 & 8.05 & 0.63 & 0.18 & 0.39 \\
\hline \multicolumn{13}{|c|}{ VFA molar proportion (\%) } \\
\hline Acetate $(\%)$ & 71.06 & 74.55 & 75.32 & 79.01 & 73.67 & 73.49 & 73.39 & 76.74 & 1.76 & 0.59 & 0.04 & 0.51 \\
\hline Propionate (\%) & 19.15 & 16.61 & 15.05 & 14.46 & 17.75 & 15.66 & 14.52 & 12.30 & 1.40 & 0.12 & 0.02 & 0.95 \\
\hline Butyrate (\%) & 8.38 & 7.05 & 6.54 & 6.39 & 6.77 & 8.03 & 8.44 & 7.39 & 0.65 & 0.37 & 0.60 & 0.03 \\
\hline Acetate/propionate & 4.07 & 4.65 & 5.08 & 5.57 & 4.58 & 4.77 & 5.07 & 6.29 & 0.51 & 0.26 & 0.44 & 0.90 \\
\hline Total $\operatorname{gas}^{2}(\mathrm{~mL} / \mathrm{g} \mathrm{DM})$ & 102.33 & 128.67 & 144.07 & 157.00 & 103.67 & 135.67 & 152.00 & 149.33 & 4.71 & 0.55 & $<0.001$ & 0.34 \\
\hline $\mathrm{CH}_{4}(\mathrm{~mL} / \mathrm{g} \mathrm{DM})$ & 6.44 & 13.60 & 16.86 & 20.66 & 6.99 & 16.76 & 21.68 & 21.47 & 1.29 & 0.07 & $<0.001$ & 0.19 \\
\hline
\end{tabular}

SEM, standard error of the mean; Trt, treatment (defaunated and refaunated); DM, dry matter.

${ }^{1} \mathrm{pH}$, ammonia and VFA analyses on samples collected from animals on $\mathrm{d} 0,7,14$, and 21 .

${ }^{2}$ Gas and methane production data collected from in-vitro incubations.

\section{production in experiment 1}

The rumen fluid $\mathrm{pH}$ was higher $(\mathrm{p}=0.02)$ in refaunated heifers, but increased $(\mathrm{p}<0.001)$ from $\mathrm{d} 0$ to $\mathrm{d} 21$ in both defaunated and refaunated heifers, showing effects of protozoal treatments and time (Table 1). Ammonia concentrations increased steadily up to $\mathrm{d} 7$ in both defaunated and refaunated heifers, but refaunated heifers had higher $\mathrm{NH}_{3}$ concentrations than did defaunated heifers $(\mathrm{p}<0.05)$. Neither VFA concentration, nor molar proportions of acetate, propionate and butyrate in total VFA, or acetate to propionate ratio were affected by protozoal treatment, but all except butyrate proportion increased over time.

There was an increase in total gas production in vitro by rumen fluid collected from both defaunated and refaunated heifers from $\mathrm{d} 0$ to 14 with no significant further increase to $\mathrm{d} 21$. There was a tendency towards a lower $\mathrm{CH}_{4}$ production from rumen fluid of defaunated heifers than from refaunated heifers over time $(p=0.07)$. No significant interaction between protozoal treatment and time was observed $(\mathrm{p}>0.05)$.

\section{In vitro fermentation pattern and methane production in experiment 2}

The $\mathrm{pH}$ after incubation was increased by the presence of protozoa and by $\mathrm{NO}_{3}$ (Table 2). Ammonia concentration was also increased by protozoal treatments and by $\mathrm{NO}_{3}$ $(\mathrm{p}<0.05)$. The presence of protozoa had little effect on VFA, with total VFA concentration tending to be lower in rumen fluid from defaunated than refaunated heifers, but VFA proportions were unaffected. VFA concentration was significantly reduced by $\mathrm{NO}_{3}$ and a significant reduction in butyrate percentage also occurred.

Methane production was reduced by both defaunation and by $\mathrm{NO}_{3}$, and there was a significant interaction between defaunation and $\mathrm{NO}_{3}$ such that mitigation resulting from $\mathrm{NO}_{3}$ and defaunation was greater than the mitigation

Table 2. The $\mathrm{pH}$, ammonia concentration, volatile fatty acid (VFA) concentration and molar proportions and methane production as influenced by the presence or absence of protozoa $\left(\mathrm{F}\right.$, fauna) or nitrate $\left(\mathrm{NO}_{3}\right)$ addition for incubations of rumen fluid in-vitro

\begin{tabular}{|c|c|c|c|c|c|c|c|c|}
\hline \multirow{3}{*}{ Item } & \multicolumn{4}{|c|}{ Treatment } & \multirow{3}{*}{ SEM } & \multicolumn{3}{|c|}{ p-values } \\
\hline & \multicolumn{2}{|c|}{ Defaunated } & \multicolumn{2}{|c|}{ Refaunated } & & \multirow{2}{*}{$\mathrm{F}$} & \multirow{2}{*}{$\mathrm{NO}_{3}$} & \multirow{2}{*}{$\mathrm{F} \times \mathrm{NO}_{3}$} \\
\hline & $-\mathrm{NO}_{3}$ & $+\mathrm{NO}_{3}$ & $-\mathrm{NO}_{3}$ & $+\mathrm{NO}_{3}$ & & & & \\
\hline$\overline{\mathrm{pH}}$ & 6.19 & 6.49 & 6.02 & 6.32 & 0.05 & $<0.01$ & $<0.01$ & 0.98 \\
\hline Ammonia (mg/L) & 101.19 & 185.71 & 167.23 & 211.70 & 11.60 & 0.01 & 0.01 & 0.18 \\
\hline Total VFA (mM/L) & 102.96 & 83.15 & 137.57 & 98.01 & 12.14 & 0.08 & 0.04 & 0.14 \\
\hline \multicolumn{9}{|c|}{ VFA molar proportion (\%) } \\
\hline Acetate $(\%)$ & 69.33 & 70.30 & 67.75 & 68.74 & 1.95 & 0.45 & 0.63 & 0.10 \\
\hline Propionate (\%) & 20.34 & 22.48 & 19.57 & 21.54 & 1.14 & 0.47 & 0.11 & 0.94 \\
\hline Butyrate $(\%)$ & 9.57 & 6.78 & 10.96 & 8.49 & 1.10 & 0.20 & 0.04 & 0.89 \\
\hline Acetate/propionate & 3.42 & 3.15 & 3.47 & 3.26 & 0.26 & 0.76 & 0.39 & 0.92 \\
\hline Total gas (mL/g DM) & 155.00 & 101.67 & 149.44 & 117.78 & 4.14 & 0.21 & $<0.01$ & 0.01 \\
\hline $\mathrm{CH}_{4}(\mathrm{~mL} / \mathrm{g} \mathrm{DM})$ & 18.59 & 3.00 & 22.11 & 12.73 & 0.63 & $<0.01$ & $<0.01$ & $<0.01$ \\
\hline
\end{tabular}

SEM, standard error of the mean; F, fauna status; DM, dry matter. 
resulting from either alone $(p<0.05)$. Methane production from defaunated heifers was lower than from refaunated ones (18.59 vs $22.11 \mathrm{~mL} / \mathrm{g} \mathrm{DM})$. While $\mathrm{NO}_{3}$ reduced the $\mathrm{CH}_{4}$ production in refaunated heifers $(12.73 \mathrm{vs} 22.11 \mathrm{~mL} / \mathrm{g}$ $\mathrm{DM})$, the combined effects of defaunation and dietary $\mathrm{NO}_{3}$ on $\mathrm{CH}_{4}$ mitigation $(19.11 \mathrm{~mL})$ was greater than the sum of effects of defaunation $(3.52 \mathrm{~mL})$ and $\mathrm{NO}_{3}(9.38 \mathrm{~mL})$, implying the combined treatments were more than additive in their mitigation potential. Total gas production was not affected by protozoal treatments ( $>0.05)$, but was reduced in incubations containing $\mathrm{NO}_{3}(\mathrm{p}<0.05)$.

\section{DISCUSSION}

The objectives of this study were to describe the changes in $\mathrm{CH}_{4}$ production and rumen fermentation characteristics associated with the reintroduction of protozoa into previously protozoa-free heifers and also assess whether $\mathrm{CH}_{4}$ mitigation arising from $\mathrm{NO}_{3}$ would be additive to that caused by the absence of protozoa. The protozoal population in previously defaunated heifers was established by $\mathrm{d} 7$ and reached $7.01 \times 10^{5}$ cells $/ \mathrm{mL}$ by d 21 comparable with that found by Morgavi et al. (2008) in sheep. These authors demonstrated that total protozoal population reached their peak at $12 \times 10^{5}$ cells $/ \mathrm{mL}$ at 25 to $30 \mathrm{~d}$ after inoculation and then stabilised at $7.6 \times 10^{5}$ cells $/ \mathrm{mL}$ from d 60 . During the refaunation period there was a substantial increase in $\mathrm{CH}_{4}$ production rate; this result was in accordance with the positive correlation between protozoa and $\mathrm{CH}_{4}$ production found by Morgavi et al. (2010) and the fact methanogens that are normally attached to protozoa (Newbold et al., 1995) are responsible for 37\% of rumen $\mathrm{CH}_{4}$ emission (Finlay et al., 1994). The present study showed that rumen fluid from previously defaunated heifers tended to have lower $\mathrm{CH}_{4}$ production in vitro than samples from refaunated heifers 7,14 , and $21 \mathrm{~d}$ after refaunation. This effect may not be exclusively a direct consequence of protozoa but also an indirect consequence of differences in bacterial and fungal populations in the presence of protozoa (Eugène et al., 2004) and in some cases, an increase in activity of $\mathrm{H}_{2}$ producers (Morgavi et al., 2012). Such compensatory changes in microbial populations after defaunation leading to an unchanged VFA pattern may explain why the absence of protozoa has caused no significant changes in $\mathrm{CH}_{4}$ emission in defaunated animals as observed from some previous studies (Bird et al., 2008; Hegarty et al., 2008; Morgavi et al., 2012).

Effects of protozoa on rumen $\mathrm{NH}_{3}$ concentrations are generally more consistent than effects on VFA concentration with the concentration of $\mathrm{NH}_{3}$ lower in defaunated ruminants compared to faunated or refaunated ones in this and previous studies (Jouany et al., 1988; Eugène et al., 2004; Santra et al., 2007; Morgavi et al., 2012; Newbold et al., 2015). Defaunation has sometimes increased total VFA concentration in defaunated sheep (Santra et al., 2007) and weaner lambs (Santra and Karim, 2002), but Hegarty et al. (2008) found total VFA was lower and the proportion of propionate was reduced in the protozoa-free lambs born from defaunated ewes. These authors suggested that effects of defaunation on reducing $\mathrm{CH}_{4}$ production may be dependent upon fermentation shifting to a more propionate rich pattern in defaunated animals. This is consistent with defaunation normally increasing the proportion of propionate and decreasing the proportion of butyrate while concomitantly reducing methane output (Eugène et al., 2004; Morgavi et al., 2012). No differences between defaunated and refaunated heifers in concentration and proportions of VFA were observed in these studies but the absence of rumen protozoa still reduced $\mathrm{CH}_{4}$ production (experiment 2), indicating that protozoal effects on methanogenesis are not just a consequence of increased partitioning of $\mathrm{H}_{2}$ into propionate synthesis.

Importantly, the successive in vitro studies showed that despite defaunation being completed $15 \mathrm{~d}$ before $\mathrm{d} 0$; the rumen of defaunated heifers was not metabolically stable, with $\mathrm{pH}$, total VFA, $\mathrm{NH}_{3}$ and $\mathrm{CH}_{4}$ production changing out to $\mathrm{d} 21$ in the experiment 1 . Little is known about rumen ecological stabilisation after defaunation, it was presumable in these studies that rumen ecology was stable within $50 \mathrm{~d}$ after defaunation and therefore was stable when the combined effects of $\mathrm{NO}_{3}$ and defaunation were assessed in experiment 2

Dietary $\mathrm{NO}_{3}$ has been shown to offer a reliable and predictable strategy to mitigate $\mathrm{CH}_{4}$ production from ruminants in both in vitro and in vivo studies. A review by Leng and Preston (2010) concluded that the use of $\mathrm{NO}_{3}$ as a hydrogen sink could reduce $\mathrm{CH}_{4}$ production from $16 \%$ to $50 \%$, depending on diets and the inclusion rate of $\mathrm{NO}_{3}$. This is because approximately 2 moles of hydrogen will be needed to convert $\mathrm{NO}_{3}$ to nitrite and 6 moles hydrogen will be removed in order to reduce nitrite to $\mathrm{NH}_{3}$ (Allison and Reddy, 1984). The result from the experiment 2 showed that $\mathrm{CH}_{4}$ production was significantly lowered by addition of $\mathrm{NO}_{3}$ in refaunated heifers $35 \mathrm{~d}$ after refaunation, confirming the potential for role of dietary $\mathrm{NO}_{3}$ as a strategy to mitigate $\mathrm{CH}_{4}$ emission (Guo et al., 2009; Nolan et al., 2010; van Zijderveld et al., 2010; 2011). In addition, $\mathrm{NO}_{3}$ reduced total gas production, total VFA concentrations and the proportion of butyrate in vitro in line with findings of Lin et al. (2011). The present study also indicated that the combined effects of protozoal treatment and dietary $\mathrm{NO}_{3}$ led to more than additive reduction in $\mathrm{CH}_{4}$ production 
$(19.11 \mathrm{~mL})$ compared with the sum of the protozoal effect $(3.52 \mathrm{~mL})$ and the dietary $\mathrm{NO}_{3}$ effect $(9.38 \mathrm{~mL})$.

\section{CONCLUSION}

Methane production was positively correlated with protozoal numbers in rumen fluid in the period following refaunation of defaunated heifers with protozoa. The absence of protozoa reduced $\mathrm{CH}_{4}$ production by $16 \%$ compared with refaunated heifers, dietary $\mathrm{NO}_{3}$ reduced $\mathrm{CH}_{4}$ production by $42 \%$ and the combined effects of $\mathrm{NO}_{3}$ and defaunation reduced $\mathrm{CH}_{4}$ production by $86 \%$. Future research is needed to confirm these suggestions and gain better understandings the changes in gut fermentation, adaptation of methanogens and increased activity of some rumen microbes after defaunation and refaunation. In vivo trials need to be undertaken to gain a better understanding of the combined effects of defaunation and dietary $\mathrm{NO}_{3}$ on $\mathrm{CH}_{4}$ production in ruminants.

\section{CONFLICT OF INTEREST}

We certify that there is no conflict of interest with any financial organization regarding the material discussed in the manuscript.

\section{ACKNOWLEDGMENTS}

This research was funded by Meat and Livestock Australia and the Australian Government Department of Agriculture, Fisheries and Forestry Carbon Farming Futures, Filling the Research Gap Program. The authors are grateful for the assistance of Dr Simon Bird and Professor John Nolan in discussions and guidance. All helps from $\mathrm{Mr}$ Graeme Bremner, Andrew Blakely and Mrs Jennies Hegarty with technical supports are acknowledged.

\section{REFERENCES}

Allison, M. J. and C. A. Reddy. 1984. Adaptations of gastrointestinal bacteria in response to changes in dietary oxalate and nitrate. In: Third International Symposium on Microbial Ecology (Eds. M. J. Klug and C. A. Reddy). Washington, DC, USA. Am. Soc. Microbiol. pp. 248-256.

Bird, S. H., R. S. Hegarty, and R. Woodgate. 2008. Persistence of defaunation effects on digestion and methane production in ewes. Aust. J. Exp. Agric. 48:152-155.

Bird, S. H. and M. N. Light. 2013. A protocol for the removal of protozoa (defaunation) from the rumen of cattle. In: Proceeding of the Recent Advances in Animal Nutrition in Australia (Ed. P. Cronje). University of New England Publishing Unit, Armidale, Australia. pp. 1-2.

Dehority, B. A. 1984. Evaluation of subsampling and fixation procedure used for counting rumen protozoa. Appl. Environ.
Microbiol. 48:182-185.

Eugène, M., H. Archimède, and D. Sauvant. 2004. Quantitative meta-analysis on the effects of defaunation of the rumen on growth, intake and digestion in ruminants. Livest. Prod. Sci. 85:81-97.

Finlay, B. J., G. Esteban, K. J. Clarke, A. G. Williams, T. M. Embley, and R. P. Hirt. 1994. Some rumen ciliates have endosymbiotic methanogens. FEMS Microbiol. Lett. 117:157161

Guo, W. S., D. M. Schaefer, X. X. Guo, L. P. Ren, and Q. X. Meng. 2009. Use of nitrate-nitrogen as a sole dietary nitrogen source to inhibit ruminal methanogenesis and to improve microbial nitrogen synthesis in vitro. Asian Australas. J. Anim. Sci. 22:542-549.

Hegarty, R. S., S. H. Bird, B. A. Vanselow, and R. Woodgate. 2008. Effects of the absence of protozoa from birth or from weaning on the growth and methane production of lambs. Br. J. Nutr. 100:1220-1227.

Jouany, J. P., D. I. Demeyer, and J. Grain. 1988. Effect of defaunating the rumen. Anim. Feed Sci. Technol. 21:229-265.

Leng, R. A. and T. R. Preston. 2010. Further considerations of the potential of nitrate as a high affinity electron acceptor to lower enteric methane production in ruminants. Livest. Res. Rural Dev. 22:221.

Lin, M., D. M. Schaefer, W. S. Guo, L. P. Ren, and Q. X. Meng. 2011. Comparisons of in vitro nitrate reduction, methanogenesis, and fermentation acid profile among rumen bacterial, protozoal and fungal fractions. Asian Australas. J. Anim. Sci. 24:471-478.

Morgavi, D. P., E. Forano, C. Martin, and C. J. Newbold. 2010. Microbial ecosystem and methanogenesis in ruminants. Animal 4:1024-1036.

Morgavi, D. P., J. P. Jouany, and C. Martin. 2008. Changes in methane emission and rumen fermentation parameters induced by refaunation in sheep. Aust. J. Exp. Agric. 48:69-72.

Morgavi, D. P., C. Martin, J. P. Jouany, and M. Ranilla. 2012. Rumen protozoa and methanogenesis: not a simple causeeffect relationship. Br. J. Nutr. 107:388-397.

Newbold, C. J., B. Lassalas, and J. P. Jouany. 1995. The importance of methanogensis associated with ciliate protozoa in ruminal methane production in vitro. Lett. Appl. Microbiol. 21:230-234.

Newbold, C. J., G. de la Fuente, A. Belanche, E. Ramos-Morales, and N. McEwan. 2015. The role of ciliate protozoa in the rumen. Front. Microbiol. 6:Article 1313.

Nolan, J. V., R. S. Hegarty, J. Hegarty, I. R. Godwin, and R. Woodgate. 2010. Effects of dietary nitrate on fermentation, methane production and digesta kinetics in sheep. Anim. Prod. Sci. 50:801-806.

Qin, W. Z., C. Y. Li, J. K. Kim, J. G. Ju, and M. K. Song. 2012. Effects of defaunation on fermentation characteristics and methane production by rumen microbes in vitro when incubated with starchy feed sources. Asian Australas. J. Anim. Sci. 25:1381-1388.

Ranilla, M. J., J. P. Jouany, and D. P. Morgavi. 2007. Methane production and substrate degradation by rumen microbial communities containing single protozoal species in vitro. Lett. Appl. Microbiol. 45:675-680. 
Santra, A. and S. A. Karim. 2002. Influence of ciliate protozoa on biochemical changes and hydrolytic enzyme profile in the rumen ecosystem. J. Appl. Microbiol. 92:801-811.

Santra, A., S. A. Karim, and O. H. Chaturvedi. 2007. Rumen enzyme profile and fermentation characteristics in sheep as affected by treatment with sodium lauryl sulfate as defaunating agent and presence of ciliate protozoa. Small Rumin. Res. 67:126-137.

Soliva, C. R. and H. D. Hess. 2007. Measuring methane emission of ruminants by in vitro and in vivo. In: Measuring Methane Production from Ruminants (Eds. P. S. M. Harinder and E. V. Philip). Springer, Netherlands. pp. 15-31.
Stumm, C. K., H. J. Gijzen, and G. D. Vogels. 1982. Association of methanogenic bacteria with ovine rumen ciliates. Br. J. Nutr. 47:95-99.

van Zijderveld, S. M., W. J. J. Gerrits, J. A. Apajalahti, J. R. Newbold, J. Dijkstra, R. A. Leng, and H. B. Perdok. 2010. Nitrate and sulfate: Effective alternative hydrogen sinks for mitigation of ruminal methane production in sheep. J. Dairy. Sci. 93:5856-5866.

van Zijderveld, S. M., W. J. J. Gerrits, J. Dijkstra, J. R. Newbold, R. B. A. Hulshof, and H. B. Perdok. 2011. Persistency of methane mitigation by dietary nitrate supplementation in dairy cows. J. Dairy Sci. 94:4028-4038. 